\title{
Phenotypic diversity in Cajanus species and identification of promising sources for agronomic traits and seed protein content
}

\author{
H. D. Upadhyaya $\cdot$ K. N. Reddy $\cdot$ Sube Singh $\cdot$ \\ C. L. L. Gowda
}

Received: 20 February 2012/ Accepted: 14 May 2012/Published online: 16 June 2012

(C) Springer Science+Business Media Dordrecht 2012

\begin{abstract}
A total of 198 accessions representing 18 species of the genus Cajanus, assembled at the ICRISAT genebank, was characterized for 27 morpho-agronomic traits at ICRISAT farm, Patancheru, India. Newman-Keuls test of significance for mean values indicated significant differences among the species for one or more traits under study. Mean diversity for all traits was maximum in $C$. scarabaeoides $\left(H^{\prime}=0.590 \pm 0.010\right)$. First three principal components (PCs) captured $84.3 \%$ of total variation among all species. Cluster analysis resulted in three clusters. C. albicans and C. mollis formed Cluster 1; C. cajanifolius, C. crassus and C. platycarpus formed Cluster 2 and C. acutifolius, C. scarabaeoides, $C$. lineatus and $C$. sericeus formed Cluster 3. C. platycarpus for extra early flowering (34-40 days); C. scarabaeoides for early flowering (51-118 days); C. albicans for broad pods; C. mollis, C. albicans, C. cinereus for more seeds per pod $(>6)$ and C. crassus, C. cajanifolius, C. mollis, C. platycarpus and C. albicans for high seed protein (>30\%) were found as promising sources. Long duration perennial species such as $C$. crassus, $C$. mollis and C. albicans are good sources for forage. Five
\end{abstract}

H. D. Upadhyaya $(\bowtie) \cdot$ K. N. Reddy $\cdot$ S. Singh

C. L. L. Gowda

International Crops Research Institute for the Semi-Arid

Tropics (ICRISAT), Genetic Resources,

Patancheru 502324, Andhra Pradesh, India

e-mail: H.Upadhyaya@CGIAR.ORG accessions (ICP 15661, ICP 15664, ICP 15666, ICP 15668 and ICP 15671) of $C$. platycarpus, two accessions (ICP 15653 and ICP 15658) of C. mollis and one accession each of $C$. acutifolius (ICP 15611), C. albicans (ICP 15620), C. cajanifolius (ICP 15632), C. crassus (ICP 15768), C. lineatus (ICP 15646), C. scarabaeoides (ICP 15922) and C. sericeus (ICP 15760), found as promising for multiple trait combinations are useful in pigeonpea improvement programs.

Keywords Cajanus species - Characterization · Diversity · Genepool · Germplasm · Wild relatives

\section{Introduction}

Pigeonpea (Cajanus cajan (L.) Millspaugh) is the sixth most important legume crop in the world with seed protein up to $31 \%$. The crop originated in India, has several special traits and finds a unique place in the farming systems adopted by the farmers in a large number of developing countries. Besides its cultivation to produce dry grains, pigeonpea is grown to culture lac-producing insects, to reduce soil erosion on sloping lands and its green seeds are used as vegetables, leaves as fodder and stems as fuel. Pigeonpea enriches soil through fixing atmospheric nitrogen by Rhizobium bacteria present in the roots. Considerable progress in pigeonpea improvement has been made by using variability within the cultivated species and 
globally, pigeonpea is grown on 4.5 million ha with a production of 3.5 million metric tons and productivity of $863 \mathrm{~kg} \mathrm{ha}^{-1}$ (FAO 2009). However, the crop still suffer from production constraints such as pod borer (Helicoverpa armigera Hübner) and podfly (Melanagromyza chalcosoma Spencer); the diseases sterility mosaic disease (SMD), wilt (Fusarium udum Butler) and phytophthora blight (Phytophthora drechsleri Tucker); and abiotic stresses such as salinity and water logging conditions.

Wild species have evolved to survive natural constraints such as droughts, floods, extreme heat, cold, pests and diseases that cause much damage to related crops. Wild species also possess genes for useful agronomic traits (Mallikarjuna et al. 2011a; Upadhyaya 2006; Upadhyaya et al. 2011). Crop wild relatives (CWR) are important components of agroecosystems as they constitute potential sources for genes for future breeding programs. Genetic base of cultivated genepools of many food crops are narrow. Discovery and incorporation of genes from wild species provide a means to sustain crop improvement. Pigeonpea breeders have a rich source of variability in the form of wild relatives, particularly in the genus Cajanus, which can play a major role in the introgression of genes for pest and disease resistance, useful agronomic traits, nutritional traits, and cytoplasmic male sterility systems (CMS) (Bohra et al. 2010; Rao et al. 2003). C. albicans was found as a source for sterility mosaic disease (SMD), pod borer and podfly resistance, high protein content, drought tolerance and high pod set; $C$. acutifolius for pod borer and podfly resistance and salinity tolerance; $C$. lineatus for SMD and podfly resistance, high protein content, salinity and drought tolerance; C. sericeus for SMD, phytophthora blight, pod borer and podfly resistance, high protein content, salinity and drought tolerance and high fruit set; $C$. volubilis (C. crassus) for SMD and high protein content; $C$. mollis for high seed protein content, C. reticulatus for pod borer resistance; C. platycarpus for phytophthora blight and pod borer resistance, salinity tolerance, early flowering, photoperiod insensitivity and high pod set are the important sources for useful genes (Bohra et al. 2010; Dodia et al. 1996; Mallikarjuna et al. 2006; Rao et al. 2003; Remanandan 1981; Saxena et al. 2002; Sharma et al. 2003; Srivastava et al. 2006).

The genebank at ICRISAT, Patancheru, India conserves 13,632 accessions of pigeonpea from 74 countries. This is the single largest collection of pigeonpea germplasm assembled in the world. The germplasm collection includes 8,215 landraces, 4,795 breeding lines, 67 improved cultivars and 555 wild accessions belonging to 66 species of six genera. The pigeonpea wild relatives' collection at ICRISAT genebank has not been characterized and evaluated systematically. Main reasons could be low seed quantity, lack of resources, difficulties in phenology and growth habit and lower priority than the cultivated species. However, limited evaluation of different species by researchers across the world indicated that the wild genepool of pigeonpea, particularly the secondary genepool is a promising source for various biotic and abiotic stresses (Bohra et al. 2010; Mallikarjuna et al. 2011a). Most of the species belonging to the secondary genepool and some species of the tertiary genepool such as $C$. platycarpus, crossable with cultivated pigeonpea either by conventional breeding or by using biotechnology tools, possess genes for useful agronomic traits and play an important role in pigeonpea improvement (Mallikarjuna et al. 2011a; Reddy et al. 2000). Therefore, the present study aims at systematic characterization of Cajanus species germplasm assembled at ICRISAT genebank for morpho-agronomic characters to assess the diversity within and between different species to enhance their utilization in pigeonpea improvement programs globally.

\section{Materials and methods}

The pigeonpea wild genepool assembled at ICRISAT genebank includes 213 accessions representing 19 species of genus Cajanus including C. acutifolius (F.v.Muell.) Maesen, C. albicans (Wight et Arn.) Maesen, C. cajanifolius (Haines) Maesen, C. cinereus (F.v.Muell.) F.v.Muell., C. confertiflorus F.v.Muell., C. crassus (Prain ex King) Maesen, C. elongatus (Benth.) Maesen, C. goensis Dalzell, C. lanceolatus (W.V.Fitzg.) Maesen, C. latisepalus (Reyn. et Pedl.) Maesen, C. lineatus (W. et A.) Maesen, C. marmoratus (R. Br. ex Benth.) F.v.Muell., C. mollis (Benth.) Maesen, C. platycarpus (Benth.) Maesen, C. reticulatus (Dryander) F.v.Muell., var. reticulatus, var. grandifolius (F.v.Muell.) Maesen, C. rugosus (Wight et Arn.) Maesen, C. scarabaeoides (L.) Thouars, $C$. sericeus (Benth. ex Baker) Maesen and C. trinervius 
(DC.) Maesen. The other related genera assembled include Rhynchosia (33 species, 303 accessions), Flemingia (8 species, 18 accessions), Eriosema (3 species and 7 accessions), Dunbaria (2 species, 12 accessions) and Paracalyx (1 species, 2 accessions). A total of 198 accessions belonging to 18 species of genus Cajanus from nine countries were characterized and evaluated at ICRISAT farm, Patancheru $\left(17.53^{\circ} \mathrm{N}\right.$, $78.27^{\circ} \mathrm{E}, 545 \mathrm{~m}$.a.s.l, and $600 \mathrm{~km}$ away from the sea), India. Because of low seed quantity available in the genebank, one accession of $C$. marmoratus, two accessions each of $C$. mollis and $C$. scarabaeoides; 3 accessions of $C$. reticulatus and 4 accessions of C. rugosus and all accessions (3) of C. trinervious were not sown and excluded from the study. Seeds of all species were scarified before sowing by giving a small cut on seed coat to overcome the problem of hard seed coat-induced dormancy. The accessions were sown in alfisol-Patancheru Soil Series (Udic Rhodustolf) precision field on 30 June 2007. Mature pods of different species were harvested depending on their maturity during 2007-2009. Accessions were grown in a single row of 8-m length with a row to row distance of 100-300 $\mathrm{cm}$ and plant to plant distance of $50-100 \mathrm{~cm}$ within the row depending upon the growth habit of the species. The soil received a basal dose of $20 \mathrm{~kg} \mathrm{~N}$ and $40 \mathrm{~kg} \mathrm{P}_{2} \mathrm{O}_{5} \mathrm{ha}^{-1}$. Standard agronomic practices were followed to raise a good crop. The crop was protected from weeds, pests and diseases to the research standards. The crop was irrigated as and when necessary. Depending upon the growth habit of some of the species, plants were given support using bamboo pegs and iron frames to overcome the problem of damage to the plants and pods due to soil contamination.

Observations were recorded on 18 qualitative traits (life cycle, growth habit, stem color, leaf color, leaflet shape, leaf hairiness, flowering pattern, base flower color, flower streak color, flower streak pattern, pod color, pod shape, pod hairiness, seed color pattern, primary seed color, secondary seed color, seed shape and seed strophiole) and 9 quantitative traits (leaflet length, leaflet width, days to $50 \%$ flowering and days to maturity (first 5 pods), pod length, pod width, seeds per pod, 100 seed weight and seed protein content following the Descriptors for Pigeonpea (IBPGR and ICRISAT 1993). Pattern of growth habit in whole plot was recorded as growth habit. Color of the stem was recorded at the time of days to $50 \%$ flowering on plot basis. Leaflet hairiness on lower surface was scored on a $1-4$ scale $(1=$ short and $4=$ long $)$. The main color of standard petals was recorded as the base color. Color of streaks on dorsal side of the vexillum (flag) was recorded as flower streak color. Pattern of streaks on the dorsal side of the flag (standard petal) was recorded as flower streak pattern. Pattern of flowering habit in whole plot was recorded as flowering pattern. Main color of pods was recorded as pod color at seed filling stage. Pod hairiness was scored on 1-6 scale $(1=$ short hairs and $6=$ long hairs). The color pattern on the seed coat was recorded after sun drying. Base color of seed coat was recorded as primary seed color. Days to $50 \%$ flowering, days to maturity (first five pods) and 100 seed weight was recorded on plot basis. Leaflet length and width was recorded on 10 fully expanded leaflets picked from three plants. Pod length, pod width and seeds per pod were recorded on 10 pods harvested from three representative plants. A random well cleaned seed sample from each plot was used to estimate seed protein content by Kjeldal method with sulphuric acid-selenium digestion, at the ICRISAT's crop quality unit (Sahrawat et al. 2002).

To assess the diversity within and between species, 184 accessions of 9 wild Cajanus species (C. acutifolius, C. albicans, C. cajanifolius, C. crassus, C. lineatus, C. mollis, C. platycarpus, C. scarabaeoides and C. sericeus) having more than three accessions and sufficient plant stand in the field were considered for data analysis. In all other species, observations were recorded on single plants. Agronomic data were analyzed using residual maximum likelihood (REML) procedure in Genstat 14 release (http://www.vsni.co.uk) to partition genotypic variance into between species and between accessions within species. The respective standard errors were estimated and used to determine the significance of variance components. Mean, range and variances were calculated for 9 quantitative characters of each species and for the entire collection. The mean values of different traits were compared using the Newman-Keuls procedure (Newman 1939; Keuls 1952). Homogeneity of phenotypic variances was tested by Levene's test (Levene 1960). Shannon and Weaver (1949) diversity index $\left(H^{\prime}\right)$ was used to measure and compare the phenotypic diversity for all 9 traits of all species. Phenotypic correlations were estimated among all quantitative characters of each species as well as over all accessions of all species and tested for their significance (Snedecor and Cochran 1980). Mean observations 
of traits were standardized by subtracting the mean value of the character from each observation and subsequently dividing by its standard deviation. This resulted in standardized values for each trait with average 0 and standardized deviation of 1 or less. The standardized values were used to perform principal component analysis (PCA) on Genstat 14 release. Cluster analysis (Ward 1963) was performed using scores of first three principal components (PCs) to group the species. Most diverse accessions were identified based on genetic distances between accessions of each species. In total, 14 best accessions of different Cajanus species possessing multiple trait combinations were identified as promising. Using Gower's dissimilarity matrix (Gower 1985), these accessions were clustered to study the grouping of species and genepool classification.

\section{Results}

Geographical distribution

The Cajanus wild species genepool assembled at ICRISAT genebank includes 213 accessions representing 19 species from nine countries (Table 1). India was the major source for Cajanus germplasm accounting for 126 accessions of 12 species followed by Australia with 31 accessions of 9 species and Sri Lanka with 29 accessions of four species. India was the predominant source for germplasm of C. scarabaeoides, $C$. platycarpus, $C$. albicans and $C$. lineatus representing 10 or more accessions each. Among the species, C. scarabaeoides (102 accessions), C. albicans (20 accessions), C. platycarpus (17 accessions) and $C$. acutifolius (12 accessions) are the major collections of Cajanus species at the ICRISAT genebank.

Diversity in the collection

\section{Qualitative traits}

Frequency distribution of different qualitative traits of Cajanus species are given in Table 9.

Life cycle All accessions of C. cajanifolius, C. lanceolatus, C. marmoratus, C. platycarpus,
C. scarabaeoides and C. cericeus, which completed life cycle in a year were grouped as annuals and all other species completing their life cycle in more than 1 year were recorded as perennials. There were six annuals and 12 perennial species in the collection.

Growth habit Five growth habits (climber, creeper, erect, spreading and semi-spreading) were observed in the collection. C. albicans, C. crassus and C. goensis were found to be climbers. C. elongatus, C. marmoratus, C. mollis, C. platycarpus, $C$. rugosus and $C$. scarabaeoides were creepers. One accession of $C$. reticulatus and all accessions of $C$. sericeus showed erect growth habit. C. acutifolius, C. confertiflorus, C. lineatus and four accessions of $C$. reticulatus had spreading growth habit. All accessions of C. cajanifolius, C. cinereus, C. lanceolatus and $C$. latisepalus showed semispreading growth habit.

Stem color Six stem colors (brown, dark brown, green, purple, green + purple and purple + green) were observed in the collection. Within C. acutifolius, two accessions had brown stems and 10 accessions had green stems. The plants of the $C$. confertiflorus accession produced a mixture of green and purple stems. In C. platycarpus, six accessions produced green stems, 9 accessions green and purple stems and one accessions purple and green stems. In C. reticulatus, one accession produced brown and one accession produced dark brown and two accessions produced green stems. In $C$. scarabaeoides, 58 accessions were with a mixture of green and purple stem plants and 42 accessions with purple and green stem plants. Plants of all other species produced green color stems. One accession of C. cajanifolius produced purple stems.

Leaf color Three leaf colors (dark green, green and light green) were observed in the collection. All accessions of $C$. albicans, $C$. crassus, C. lineatus, 16 accessions of $C$. platycarpus and one accession of C. reticulatus produced dark green leaves. One accession of $C$. acutifolius and one accession of C. latisepalus produced light green leaves. Plants of all accessions of other species possessed green leaves.

Leaflet shape All accessions of all species produced trifoliate leaves. Six leaflet shapes were found in the collection of Cajanus. All accessions of C. mollis 


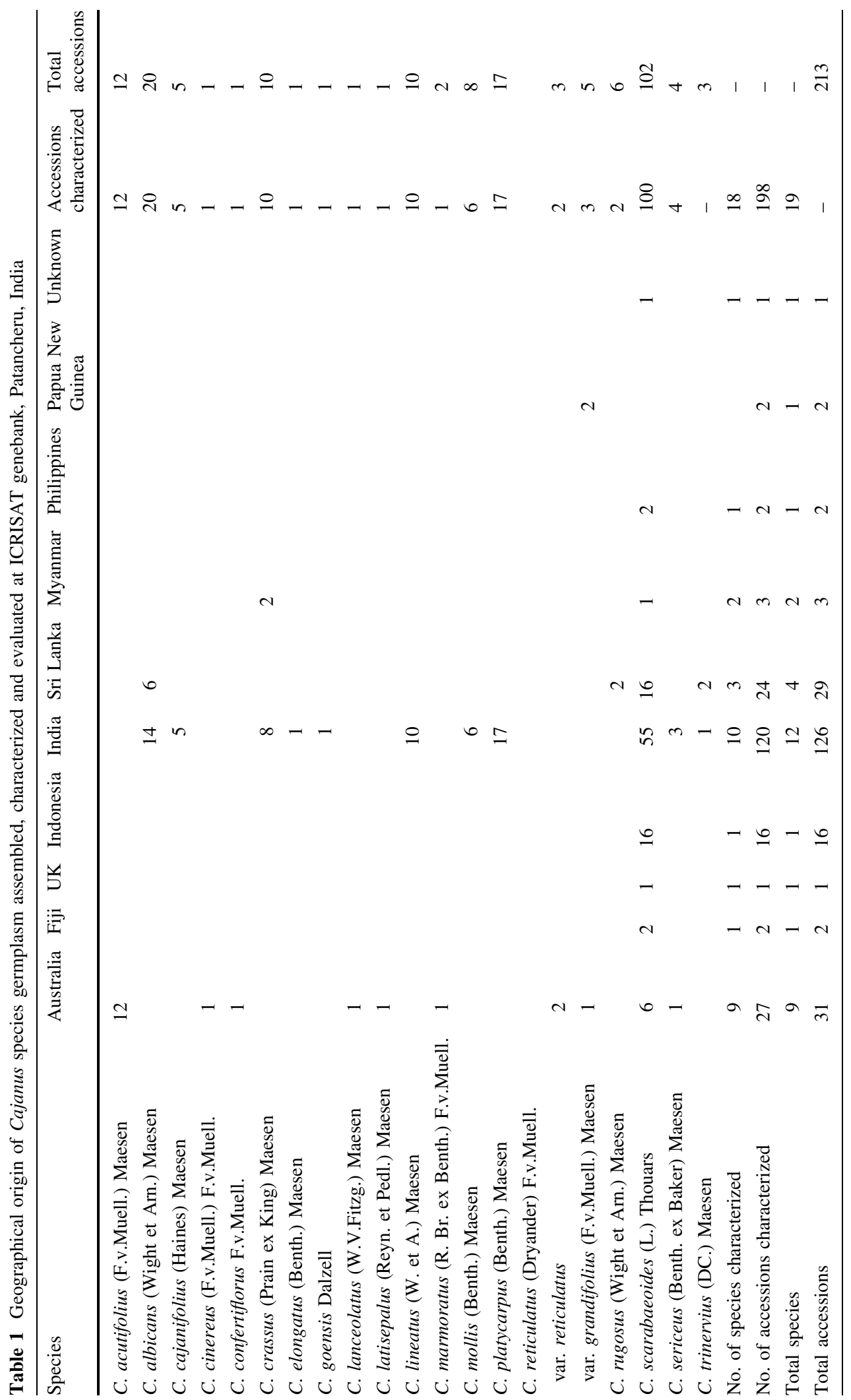


produced elliptic leaflets. All accessions of $C$. acutifolius, C. cajanifolius, C. lanceolatus and $C$. lineatus produced lanceolate leaflets. Leaflet shape was oblanceolate in C. sericeus; obovate in C. albicans, C. confertiflorus, C. elongatus, C. rugosus and $C$. scarabaeoides; ovate in C. cinereus, C. goensis, $C$. latisepalus, C. platycarpus and C. reticulatus, and rhomboidal in $C$. crassus and $C$. marmoratus.

Leaflet hairiness Leaflets of all accessions of all species were hairy. Except $C$. lineatus, leaves of all species scored 1-2 for leaf hairiness. Eight accessions of $C$. lineatus scored 3 and two accessions scored 4 for leaf hairiness.

Flowering pattern This was a monomorphic trait. All accessions of all species showed indeterminate flowering habit.

Base flower color This was a monomorphic trait and all the accessions of all species produced basically yellow flowers.

Flower streak color Four flower streak colors (no streaks, purple, red and red + no streaks) were observed in the collection. Red color streaks were predominant in $C$. acutifolius, C. albicans, C. cajanifolius, $C$. cinereus, C. confertiflorus, C. elongatus, C. lanceolatus, C. latisepalus. C. reticulatus and C. scarabaeoides. Flowers with no streak color were observed in one accession of $C$. albicans, nine accessions each of C. crassus and C. lineatus; all accessions of C. goensis, C. marmoratus, C. mollis, C. platycarpus, C. sericeus and $C$. rugosus; 12 accessions of $C$. scarabaeoides and one accession of $C$. reticulatus.

Flower streak pattern Five classes were observed for this trait. Dense streaks were found in one accession of $C$. acutifolius, 10 accessions of C. albicans, 3 accessions of $C$. cajanifolius and one accession each of $C$. cinereus, $C$. lanceolatus and C. scarabaeoides. Few streak pattern was observed in 51 accessions belonging to $C$. acutifolius (2), C. albicans (9), C. confertiflorus (1) C. elongatus (1), C. lineatus (1), C. reticulatus (1) and C. scarabaeoides (36). Medium streaks were observed in 63 accessions belonging to $C$. acutifolius (9), C. cajanifolius (2), C. crassus (1), C. latisepalus (1), C. reticulatus (1) and
C. scarabaeoides (49). Two accessions of $C$. scarabaeoides were with a mixture of plants producing medium streaks and no streaks. As many as 63 accessions of 11 species produced no streaks.

Pod color Two classes (green and mixed) of pod color were found in the collection. Except 3 accessions of C. cajanifolius, one accession each of C. marmoratus and C. platycarpus, which produced mixed color pods, all accessions of all other species only produced green pods.

Pod shape Only two classes (cylindrical and flat) were observed for this trait. Except one accession each of C. cajanifolius and C. elongatus and four accessions of $C$. sericeus, which produced cylindrical pods, all accessions of other species produced flat pods.

Podhairiness Pods of all accessions of C. acutifolius, C. albicans, C. cajanifolius, C. cinereus, C. crassus, C. elongatus, C. mollis and C. rugosus produced relatively short hairs with a score ranging from 1 to 3 . On the other hand, $C$. goensis, $C$. lanceolatus, $C$. latisepalus and $C$. lineatus, C. marmoratus, C. platycarpus, C. reticulatus, C. scarabaeoides and C. sericeus produced longer hairs with a score ranging from 4 to 6 .

Seed color pattern In the collection, three solitary (mottled, plain and speckled) and four mixed (mottled + plain, plain + mottled, plain + speckled and speckled + plain) seed color patterns were found. Mottled pattern was predominant in most of the species. C. rugosus and C. goensis produced plain and speckled seed color patterns, respectively.

Primary seed color Six primary seed colors were observed in the collection. Only one accession of C. lineatus produced brown seeds. The seed color of C. rugosus was dark purple. Primary seed colors of all other species were variants of gray ranging from light gray to dark gray. About $54 \%$ of total accessions produced dark gray colored seeds.

Secondary seed color Six classes (black, dark gray, gray, gray brown, light gray and none) were observed for this trait. One accession each of $C$. marmoratus and C. mollis produced black seeds. Seeds of 39 accessions of $C$. scarabaeoides and 2 accessions of $C$. rugosus have no secondary color. Seeds of all other species 
produced variants of gray as secondary color. About $62 \%$ of accessions of 15 species produced seeds having gray as secondary seed color.

Seed shape Three seed shapes (elongate, square, and oval) were found in the collection. Six accessions of $C$. platycarpus produced elongate seeds and one accession produced elongate and square seeds. Seeds of $C$. goensis, $C$. latisepalus and $C$. marmoratus were of oval shape. All accessions of other species produced square shape seeds.

Seed strophiole This was the important diagnostic trait to identify wild species. Seed strophiole was observed in seeds of all accessions of all species, in C. cajan it is very rare.

\section{Quantitative traits}

(REML) analysis Genotypic variance $\left(\sigma^{2} \mathrm{~g}\right)$ was significant for all the traits in the entire set $(184$ accessions) and in all species except $C$. sericeus (4 accessions), $C$. cajanifolius (5 accessions), and C. mollis (8 accessions). The genotypic variances estimated for all traits of all species (with $>8$ accessions) and entire collection revealed significant differences among species (Table 2). Highly significant $(P<0.0001) \quad$ Wald $\quad(1943)$ statistics revealed significant differences among the species.

Range and means Wide variation was observed in C. acutifolius for leaf width (1.6-9.5 mm) and days to maturity (130-290 days); in C. albicans for pod width $(9.6-15.0 \mathrm{~mm})$ and seeds per pod $(4.8-7.2)$; in C. crassus for leaflet length $(8.3-11.3 \mathrm{~cm})$; in C. mollis for days to $50 \%$ flowering (222-392 days) and in C. platycarpus for pod length $(3.5-4.7 \mathrm{~cm})$, 100-seed weight (3.8-6.9 g) and seed protein content (17.9-33.3\%) (Table 3). Minimum and maximum values for different traits indicated $C$. crassus for long and broad leaflets; $C$. mollis for long pods; $C$. albicans for late flowering (days to $50 \%$ flowering $=460$ 502 days), maturity (510-560 days) and broad pods (up to $15 \mathrm{~mm}$ ); C. mollis for more seeds per pod (8.6); C. platycarpus for large seeds $\left(6.9 \mathrm{~g} 100\right.$ seeds $\left.^{-1}\right)$ and C. crassus for high seed protein content $(33.8 \%)$ are the important sources. On the other hand, days to $50 \%$ flowering in C. platycarpus ranged from 34 to 40 days

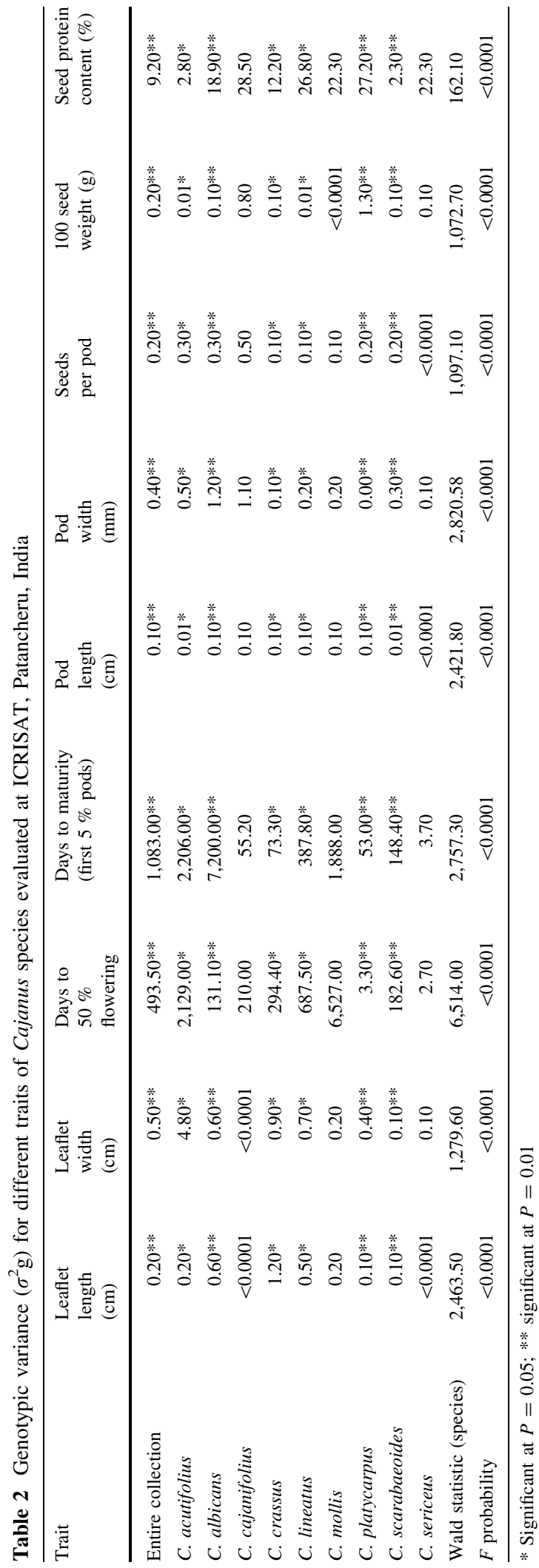


and maturity from 64 to 84 days) and it ranged from 51 to 118 days in $C$. scarabaeoides.

Newman-Keuls (Newman 1939; Keuls 1952) test of significance for mean values indicated significant differences among the species for one or more traits under study (Table 4). C. crassus produced long $(9.7 \mathrm{~cm})$ and broad leaflets $(8.4 \mathrm{~mm})$ and differed significantly from all other species for these traits. Whereas, $C$. sericeus produced short leaflets and $C$. lineatus produced narrow leaflets. C. albicans flowered and matured very late and differed significantly with all other species. In this respect, $C$. platycarpus was extra early for flowering (36 days) and maturity (74 days) and produced larger seeds (5.7 g 100 seeds ${ }^{-1}$ ) and differed significantly from all other species for these traits. C. scarabaeoides, which is crossable with cultivated pigeonpea and possess resistant genes for several biotic and abiotic stresses, flowered early (70 days) and matured early too (126 days). C. mollis produced longest pods $(4.6 \mathrm{~cm})$ among wild species with more seeds per pod (8.3) and differed significantly from all other species for these traits. C. albicans produced broader pods than all other wild species. C. crassus had highest seed protein content $(28.3 \%)$ but did not differed significantly from C. cajanifolius $(27.2 \%)$, C. sericeus (26.7\%), C. lineatus (26.5\%), C. albicans (25.5\%), C. mollis $(25.1 \%)$ and C. platycarpus $(23.8 \%)$. Raw data of other species, which were not included in the analysis (few accessions) indicated longest leaflets in C. reticulatus $(12.5 \mathrm{~cm})$ and very late flowering (520 days) and maturity (555 days) in C. goensis.

Variances The homogeneity of variances of the species was tested for all the nine quantitative traits by Levene's test (Levene 1960) (Table 4). The variances were heterogeneous $(P \leq 0.0001)$ for leaflet length, days to $50 \%$ flowering, pod length, 100 seed weight and seed protein content. Variance for leaflet width was significant only at $5 \%$.

Diversity The Shannon-Weaver diversity index $\left(H^{\prime}\right)$ (Shannon and Weaver 1949) was calculated over all accessions of all species and for each species to compare phenotypic diversity among the species for nine quantitative traits (Table 5). A low $H^{\prime}$ indicates extremely unbalanced frequency classes for an individual trait and lack of genetic diversity in the collection or species. The diversity index values $\left(H^{\prime}\right)$ were variable among traits. In the entire collection, diversity index $\left(H^{\prime}\right)$ ranged from $0.313 \pm 0.026$ for days to $50 \%$ flowering to $0.553 \pm 0.026$ for seed protein content. Mean diversity over all traits was maximum in $C$. scarabaeoides $\left(H^{\prime}=0.590 \pm 0.010\right)$ and it was lowest in $C$. sericeus $\left(H^{\prime}=0.322 \pm\right.$ 0.051). Accessions of $C$. scarabaeoides were found to be highly diverse for leaflet length and width, days to maturity, pod width, 100 seed weight and seed protein content. Similarly, accessions of $C$. albicans were diverse for days to $50 \%$ flowering and seeds per pod and those of $C$. platycarpus were highly diverse for pod length (Table 5).

Cluster analysis Principal component analysis was carried out using standardized data of nine quantitative traits. First three PCs captured $84.3 \%$ of total variation. A hierarchical cluster analysis (Ward 1963) conducted on the scores of the first three PCs resulted in three clusters (Fig. 1). C. albicans and C. mollis formed Cluster 1; C. cajanifolius, C. crassus and $C$. platycarpus formed Cluster 2 and C. acutifolius, C. scarabaeoides, C. lineatus and C. sericeus formed Cluster 3.

Characterassociations Correlation coefficients were also calculated for different trait combinations in each species and over all accessions of all species. Skinner et al. (1999) suggested that correlation coefficients greater than 0.707 or less than -0.707 are biologically meaningful, so that at least $50 \%$ of the variation in one trait is predicted by the other. The trait combinations showing meaningful correlations in different species and over all accessions of all species are given in Table 6. A total of 28 trait combinations showed correlations greater than 0.707 or less than -0.707 . Twenty of these were positive and eight were negative correlations. Leaf length and leaf width showed strong correlation ( $r=0.825-0.931)$ in C. albicans, C. mollis and across all tested species. Days to $50 \%$ flowering and days to maturity had strong positive correlation in C. acutifoilus, C. crassus, C. lineatus, C. platycarpus, C. scarabaeoides and over all species. Pod length with pod width in $C$. sericeus, pod length with seeds per pod in C. lineatus and with 100-seed weight in C. platycarpus also showed significant positive correlation (Table 6). Correlations were positive between pod width and seeds per pod in 
Table 3 Range of variation for different traits of Cajanus species evaluated at ICRISAT, Patancheru, India

\begin{tabular}{|c|c|c|c|c|c|c|c|c|c|}
\hline Species & $\begin{array}{l}\text { Leaflet } \\
\text { length } \\
(\mathrm{cm})\end{array}$ & $\begin{array}{l}\text { Leaflet } \\
\text { width } \\
(\mathrm{cm})\end{array}$ & $\begin{array}{l}\text { Days to } \\
50 \% \\
\text { flowering }\end{array}$ & $\begin{array}{l}\text { Days to } \\
\text { maturity (first } \\
5 \% \text { pods) }\end{array}$ & $\begin{array}{l}\text { Pod } \\
\text { length } \\
(\mathrm{cm})\end{array}$ & $\begin{array}{l}\text { Pod } \\
\text { width } \\
(\mathrm{mm})\end{array}$ & $\begin{array}{l}\text { Seeds } \\
\text { per } \\
\text { pod }\end{array}$ & $\begin{array}{l}100 \text { seed } \\
\text { weight } \\
\text { (g) }\end{array}$ & $\begin{array}{l}\text { Seed } \\
\text { protein } \\
\text { content }(\%)\end{array}$ \\
\hline Entire collection & $2.3-11.3$ & $1.1-9.6$ & $34-502$ & $64-560$ & $1.2-5.0$ & $1.3-15.0$ & $2.0-8.6$ & $1.1-6.9$ & $16.3-33.8$ \\
\hline C. acutifolius & $4.1-5.5$ & $1.6-9.5$ & $60-220$ & $130-290$ & $2.0-2.5$ & $6.6-9.0$ & $2.8-4.4$ & $2.1-2.4$ & $16.3-20.7$ \\
\hline C. albicans & $4.4-6.8$ & $3.1-5.8$ & $460-502$ & $510-560$ & $3.4-4.4$ & $9.6-15.0$ & $4.8-7.2$ & $1.7-2.8$ & $20.1-32.5$ \\
\hline C. cajanifolius & $6.1-6.5$ & $2.1-2.4$ & $84-120$ & $140-158$ & $3.8-4.5$ & $7.8-10.0$ & $3.6-5.2$ & $3.5-5.8$ & $19.3-33.6$ \\
\hline C. crassus & $8.3-11.3$ & $6.5-9.6$ & $140-198$ & $220-240$ & $3.1-4.2$ & $9.6-10.6$ & $4.4-5.3$ & $3.2-4.1$ & $20.3-33.8$ \\
\hline C. lineatus & $3.3-5.7$ & $1.1-4.1$ & $160-220$ & $220-270$ & $1.5-2.4$ & $8.0-9.4$ & $2.0-2.8$ & $1.8-2.3$ & $18.2-30.2$ \\
\hline C. mollis & $6.0-7.0$ & $3.9-5.1$ & $222-392$ & $310-420$ & $4.2-5.0$ & $7.0-8.2$ & $7.9-8.6$ & $1.6-2.1$ & $21.7-33.4$ \\
\hline C. platycarpus & $5.7-7.1$ & $5.1-6.9$ & $34-40$ & $64-84$ & $3.5-4.7$ & $1.3-1.6$ & $4.0-6.0$ & $3.8-6.9$ & $17.9-33.3$ \\
\hline C. scarabaeoides & $2.3-3.8$ & $1.4-2.4$ & $51-118$ & $102-168$ & $1.8-2.7$ & $5.6-8.4$ & $3.6-5.8$ & $1.1-2.9$ & $17.8-27.1$ \\
\hline C. sericeus & $2.3-2.6$ & $5.2-5.8$ & $98-102$ & $134-138$ & $1.2-1.4$ & $6.0 .4-7$ & $2.0-2.0$ & $1.4-2.3$ & 20.9-30.6 \\
\hline
\end{tabular}

Table 4 Mean values $^{\mathrm{a}}$ and variances for different traits of Cajanus species evaluated at ICRISAT, Patancheru, India

\begin{tabular}{|c|c|c|c|c|c|c|c|c|c|}
\hline Species & $\begin{array}{l}\text { Leaflet } \\
\text { length } \\
(\mathrm{cm})\end{array}$ & $\begin{array}{l}\text { Leaflet } \\
\text { width } \\
(\mathrm{cm})\end{array}$ & $\begin{array}{l}\text { Days to } \\
50 \% \\
\text { flowering }\end{array}$ & $\begin{array}{l}\text { Days to } \\
\text { maturity (first } \\
5 \% \text { pods) }\end{array}$ & $\begin{array}{l}\text { Pod } \\
\text { length } \\
(\mathrm{cm})\end{array}$ & $\begin{array}{l}\text { Pod } \\
\text { width } \\
(\mathrm{mm})\end{array}$ & $\begin{array}{l}\text { Seeds } \\
\text { per } \\
\text { pod }\end{array}$ & $\begin{array}{l}100 \text { seed } \\
\text { weight } \\
\text { (g) }\end{array}$ & $\begin{array}{l}\text { Seed } \\
\text { protein } \\
\text { content }(\%)\end{array}$ \\
\hline C. acutifolius & $4.52 \mathrm{~d}$ & $2.56 \mathrm{~d}$ & $174.17 \mathrm{dc}$ & $246.67 \mathrm{c}$ & $2.25 \mathrm{~d}$ & $7.90 \mathrm{~d}$ & $3.39 \mathrm{e}$ & $2.26 \mathrm{~d}$ & $18.56 \mathrm{~b}$ \\
\hline C. albicans & $5.28 \mathrm{c}$ & $4.29 \mathrm{c}$ & $483.40 \mathrm{a}$ & $516.50 \mathrm{a}$ & $3.77 \mathrm{c}$ & $11.36 \mathrm{a}$ & $6.14 \mathrm{~b}$ & $2.34 \mathrm{~d}$ & $25.48 \mathrm{a}$ \\
\hline C. cajanifolius & $6.27 \mathrm{~b}$ & $2.24 \mathrm{~d}$ & $96.00 \mathrm{e}$ & $146.80 \mathrm{~d}$ & $4.08 \mathrm{~b}$ & $8.76 \mathrm{c}$ & $4.12 \mathrm{~d}$ & $4.28 \mathrm{~b}$ & $27.20 \mathrm{a}$ \\
\hline C. crassus & $9.70 \mathrm{a}$ & $8.43 \mathrm{a}$ & $163.00 \mathrm{~d}$ & $231.70 \mathrm{c}$ & $3.59 \mathrm{c}$ & $10.16 \mathrm{~b}$ & $4.81 \mathrm{c}$ & $3.61 \mathrm{c}$ & $28.25 \mathrm{a}$ \\
\hline C. lineatus & $4.27 \mathrm{~d}$ & $1.77 \mathrm{~d}$ & $190.20 \mathrm{c}$ & $239.00 \mathrm{c}$ & $1.97 \mathrm{e}$ & $8.60 \mathrm{c}$ & $2.27 \mathrm{f}$ & $2.07 \mathrm{~d}$ & $26.50 \mathrm{a}$ \\
\hline C. mollis & $6.49 \mathrm{~b}$ & $4.42 \mathrm{c}$ & $286.17 \mathrm{~b}$ & $346.00 \mathrm{~b}$ & $4.56 \mathrm{a}$ & $7.68 \mathrm{~d}$ & $8.26 \mathrm{a}$ & $1.93 \mathrm{~d}$ & $25.08 \mathrm{a}$ \\
\hline C. platycarpus & $6.35 \mathrm{~b}$ & $6.07 \mathrm{~b}$ & $36.24 \mathrm{~g}$ & $74.41 \mathrm{e}$ & $4.12 \mathrm{~b}$ & $1.43 \mathrm{f}$ & $4.98 \mathrm{c}$ & $5.72 \mathrm{a}$ & $23.81 \mathrm{a}$ \\
\hline C. scarabaeoides & $3.09 \mathrm{e}$ & $1.90 \mathrm{~d}$ & $70.37 \mathrm{f}$ & $126.33 \mathrm{~d}$ & $2.23 \mathrm{~d}$ & $6.96 \mathrm{e}$ & $4.88 \mathrm{c}$ & $1.81 \mathrm{~d}$ & $20.31 \mathrm{~b}$ \\
\hline C. sericeus & $2.46 \mathrm{f}$ & $5.50 \mathrm{~b}$ & $100.00 \mathrm{e}$ & $135.50 \mathrm{~d}$ & $1.26 \mathrm{f}$ & $6.55 \mathrm{e}$ & $2.00 \mathrm{f}$ & $1.80 \mathrm{~d}$ & $26.70 \mathrm{a}$ \\
\hline$F$ value (variance) & 11.16 & 17.17 & 17.13 & 1.14 & 4.87 & 1.89 & 1.20 & 20.36 & 10.15 \\
\hline$P$ & $<0.0001$ & 0.0321 & $<0.0001$ & 0.3406 & $<0.0001$ & 0.0639 & 0.301 & $<0.0001$ & $<0.0001$ \\
\hline \multicolumn{10}{|c|}{ Species not considered for statistical analysis } \\
\hline C. reticulatus & 8.9 & 5.9 & 325 & 360 & 2.6 & 7.9 & 3.7 & 1.7 & 24.1 \\
\hline C. rugosus & 5.9 & 4.4 & 452 & 360 & 2.6 & 7.9 & 3.7 & 1.6 & 24.1 \\
\hline C. cinereus & 6.9 & 5.2 & 175 & 255 & 4.5 & 9.2 & 6.0 & 2.9 & 19.4 \\
\hline C. confertiflorus & 7.7 & 6.4 & 360 & - & - & - & - & 2.0 & - \\
\hline C. elongatus & 3.0 & 2.2 & 237 & 300 & - & - & - & 1.3 & - \\
\hline C. goensis & 4.8 & 4.6 & 520 & 555 & 4.7 & 7.8 & 5.8 & 2.9 & - \\
\hline C. lanceolatus & 10.5 & 3.6 & 135 & 198 & 3.6 & 8.4 & 4.8 & 4.1 & 16.9 \\
\hline C. latisepalus & 7.6 & 4.0 & 160 & 260 & 2.9 & 9.2 & 3.2 & 2.4 & - \\
\hline C. marmoratus & 3.2 & 4.0 & 85 & 134 & 2.8 & 12.8 & 3.6 & 6.9 & 16.8 \\
\hline
\end{tabular}

${ }^{a}$ Means were tested by Newman-Keuls test and means followed by different letters are significantly different at $P=0.05$

C. cajanifolius and C. crassus and between seeds per pod and seed protein content in C. acutifolius. Days to $50 \%$ flowering had highest positive correlation with
100 -seed weight $(r=0.982)$ in $C$. sericeus. Days to $50 \%$ flowering had shown significant negative correlation with pod length and 100-seed weight in $C$. 
Table 5 Shannon-Weaver diversity indices $\left(H^{\prime}\right)$ for important agronomic traits of different Cajanus species, evaluated at ICRISAT, Patancheru, India

\begin{tabular}{|c|c|c|c|c|c|c|c|c|c|c|c|}
\hline Species & $\begin{array}{l}\text { Leaflet } \\
\text { length } \\
(\mathrm{cm})\end{array}$ & $\begin{array}{l}\text { Leaflet } \\
\text { width } \\
(\mathrm{cm})\end{array}$ & $\begin{array}{l}\text { Days to } \\
50 \% \\
\text { flowering }\end{array}$ & $\begin{array}{l}\text { Days to } \\
\text { maturity } \\
\text { (first } 5 \% \\
\text { pods) }\end{array}$ & $\begin{array}{l}\text { Pod } \\
\text { length } \\
(\mathrm{cm})\end{array}$ & $\begin{array}{l}\text { Pod } \\
\text { width } \\
(\mathrm{mm})\end{array}$ & $\begin{array}{l}\text { Seeds } \\
\text { per } \\
\text { pod }\end{array}$ & $\begin{array}{l}100 \\
\text { seed } \\
\text { weight }(\mathrm{g})\end{array}$ & $\begin{array}{l}\text { Seed } \\
\text { protein } \\
\text { content } \\
(\%)\end{array}$ & Mean & SE \\
\hline Entire collection & 0.479 & 0.421 & 0.313 & 0.374 & 0.531 & 0.481 & 0.525 & 0.425 & 0.553 & 0.456 & 0.0264 \\
\hline C. acutifolius & 0.364 & 0.125 & 0.537 & 0.521 & 0.477 & 0.537 & 0.244 & 0.439 & 0.468 & 0.412 & 0.0478 \\
\hline C. albicans & 0.427 & 0.566 & 0.580 & 0.086 & 0.532 & 0.434 & 0.597 & 0.506 & 0.471 & 0.467 & 0.0518 \\
\hline C. cajanifolius & 0.413 & 0.458 & 0.217 & 0.458 & 0.413 & 0.413 & 0.413 & 0.217 & 0.413 & 0.379 & 0.0313 \\
\hline C. crassus & 0.473 & 0.530 & 0.507 & 0.473 & 0.473 & 0.473 & 0.473 & 0.556 & 0.473 & 0.492 & 0.0105 \\
\hline C. lineatus & 0.518 & 0.278 & 0.447 & 0.447 & 0.530 & 0.507 & 0.507 & 0.458 & 0.415 & 0.456 & 0.0259 \\
\hline C. mollis & 0.439 & 0.439 & 0.276 & 0.217 & 0.458 & 0.458 & 0.458 & 0.377 & 0.217 & 0.371 & 0.0350 \\
\hline C. platycarpus & 0.516 & 0.588 & 0.474 & 0.476 & 0.573 & 0.524 & 0.523 & 0.368 & 0.416 & 0.495 & 0.0236 \\
\hline C. scarabaeoides & 0.615 & 0.635 & 0.554 & 0.612 & 0.555 & 0.591 & 0.551 & 0.609 & 0.587 & 0.590 & 0.0102 \\
\hline C. sericeus & 0.452 & 0.301 & 0.452 & 0.452 & 0.244 & 0.244 & 0.000 & 0.452 & 0.301 & 0.322 & 0.0505 \\
\hline
\end{tabular}

Fig. 1 Dendrogram showing the clusters of Cajanus species based on first three principal components $(84.3 \%$ variation)

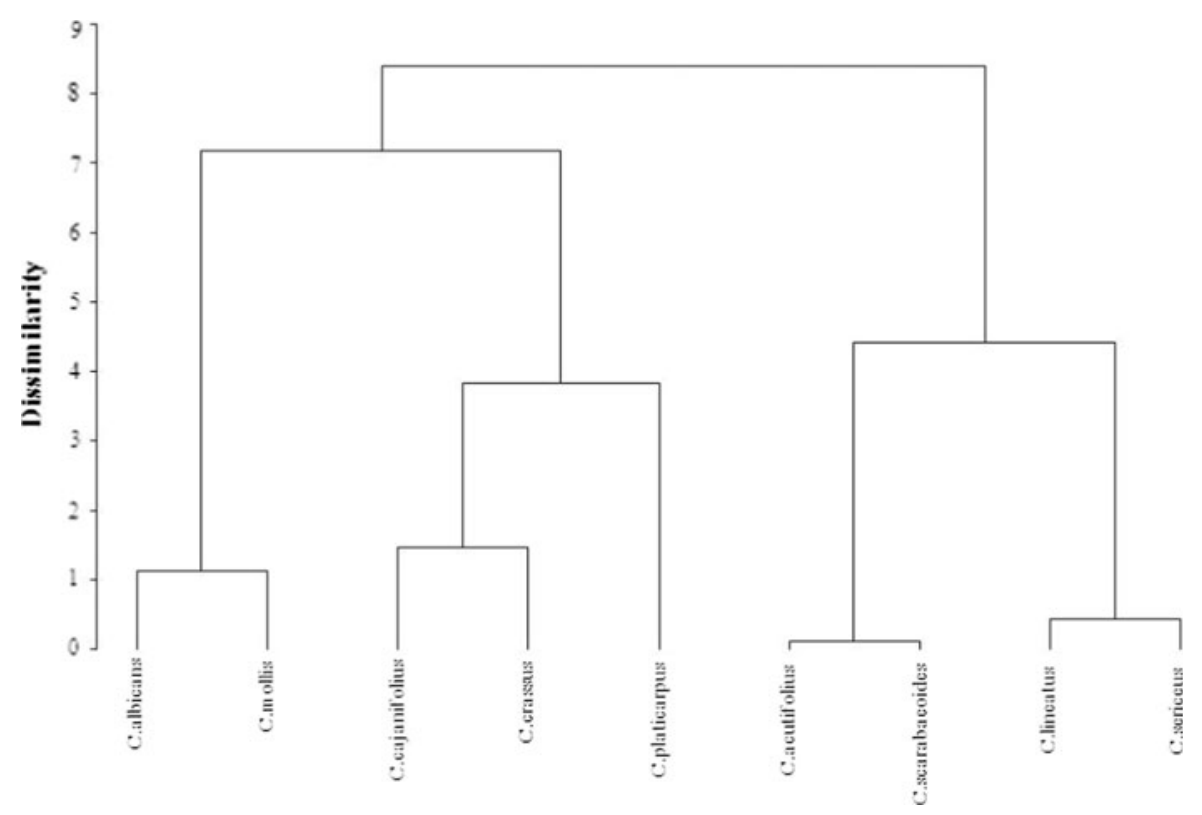

Promising sources identified

Five accessions of $C$. platycarpus, two accessions of $C$. mollis and one accession each of $C$. acutifolius, C. albicans, C. cajanifolius, C. crassus, C. lineatus, $C$. scarabaeoides and $C$. sericeus were found as promising for multiple trait combinations (Table 7). These 14 accessions were clustered using Gower's 
Table 6 Important correlation coefficients $(r \geq 0.707$ and $<0.707)$ for different traits of Cajanus species, evaluated at ICRISAT, Patancheru, India

\begin{tabular}{|c|c|c|}
\hline Trait combination & Species & $r$ value \\
\hline \multirow[t]{3}{*}{ Leaflet length and width } & All species & 0.825 \\
\hline & C. albicans & 0.931 \\
\hline & C. mollis & 0.876 \\
\hline Leaflet length and pod length & All species & 0.746 \\
\hline \multirow[t]{2}{*}{ Leaflet width and days to maturity } & C. cajanifolius & 0.938 \\
\hline & C. platycarpus & 0.745 \\
\hline \multirow{6}{*}{$\begin{array}{l}\text { Days to } 50 \% \text { flowering } \\
\text { and days to maturity }\end{array}$} & All species & 0.963 \\
\hline & C. acutifolius & 0.893 \\
\hline & C. crassus & 0.733 \\
\hline & C. lineatus & 0.909 \\
\hline & C. platycarpus & 0.827 \\
\hline & $\begin{array}{l}\text { C. } \\
\quad \text { scarabaeoides }\end{array}$ & 0.865 \\
\hline $\begin{array}{l}\text { Days to } 50 \% \text { flowering } \\
\text { and pod length }\end{array}$ & C. platycarpus & -0.761 \\
\hline $\begin{array}{l}\text { Days to } 50 \% \text { flowering } \\
\text { and seeds per pod }\end{array}$ & C. acutifolius & -0.819 \\
\hline \multirow{2}{*}{$\begin{array}{l}\text { Days to } 50 \% \text { flowering } \\
\text { and } 100 \text {-seed weight }\end{array}$} & C. platycarpus & -0.840 \\
\hline & C. sericeus & 0.982 \\
\hline \multirow[t]{3}{*}{ Days to maturity and pod width } & All species & 0.729 \\
\hline & C. mollis & -0.891 \\
\hline & C. platycarpus & -0.728 \\
\hline Days to maturity and seeds per pod & C. acutifolius & -0.762 \\
\hline $\begin{array}{l}\text { Days to maturity and } 100 \text {-seed } \\
\text { weight }\end{array}$ & C. platycarpus & -0.838 \\
\hline Pod length and pod width & C. sericeus & 0.974 \\
\hline Pod length and seeds per pod & C. lineatus & 0.829 \\
\hline Pod length and 100-seed weight & C. platycarpus & 0.882 \\
\hline \multirow[t]{3}{*}{ Pod width and seeds per pod } & C. cajanifolius & 0.891 \\
\hline & C. crassus & 0.765 \\
\hline & C. mollis & -0.858 \\
\hline $\begin{array}{l}\text { Seeds per pod and seed protein } \\
\text { content }\end{array}$ & C. acutifolius & 0.793 \\
\hline
\end{tabular}

dissimilarity matrix (Gower 1985) to study the grouping of accessions belonging to different genepools. Accessions of C. acutifolius, C. cajanifolius, C. scarabaeoides, C. albicans, C. crassus and C. lineatus formed Cluster 1; accessions of $C$. mollis and $C$. sericeus formed Cluster 2 and all accessions of C. platycarpus formed Cluster 3 (Fig. 2). In Cluster 1, only $C$. crassus belongs to the tertiary genepool and other species belong to the secondary genepool. On the other hand, Cluster 2 consists of species belonging to secondary (C. sericeus) and tertiary (C. mollis) genepool. Results indicated deviation of C. platycarpus from all other species for traits under study. ICP 15768 (C. crassus); ICP 15632 (C. cajanifolius); ICP 15653 (C. mollis); ICP 15666, ICP 15668, ICP 15671 and ICP 15661 (C. platycarpus); ICP 15620 (C. albicans) and ICP 15760 (C. sericeus) have produced more than $30 \%$ seed protein content (Table 7). One accession of C. platycarpus (ICP 15666) flowered in 39 days, produced more than five seeds per pod and had $33.3 \%$ seed protein. Four accessions of $C$. platycarpus (ICP 15661, ICP 15666, ICP 15668 and ICP 15671) were extra early flowering (34-37 days) and maturity (64-84 days) and also produced seeds having more than $30 \%$ protein. Accessions of C. mollis (ICP 15653 and ICP 15658) produced more than 7 seeds per pod are the promising sources for higher number of seeds per pod. Perennial species such as $C$. albicans, $C$. crassus and $C$. mollis, which produced large leaves and have high seed protein $(>30 \%)$ are good sources for forage also.

Most diverse and least diverse pairs of accessions were identified in each species for utilization in crop improvement programs (Table 8). ICP 15655 and ICP 15653 of $C$. mollis were found as the most diverse accessions in the collection with maximum distance (0.671) followed by ICP 15612 and ICP 15610 of C. acutifolius (0.555). ICP 15708 and ICP 15697 of C. scarabaeoides were found as the most similar with zero distance.

\section{Discussion}

Genebanks are able to conserve only a fraction of the total variability that exists in the wild relatives of the crops (Jarvis et al. 2008). The revised genus Cajanus consists of 32 species including the cultivated species Cajanus cajan. Of the 31 wild species, 13 are endemic to Australia, eight to Indian subcontinent and Myanmar, one to West Africa and rest of the species occur in more than one country (van der Maesen 1990). Though Eastern Africa is considered as the secondary center of diversity for pigeonpea, none of the East African countries were represented in the collection of Cajanus germplasm. The summary of Cajanus germplasm at ICRISAT genebank indicates wide 
Table 7 Promising accessions of Cajanus species identified for multiple trait combinations

\begin{tabular}{|c|c|c|c|c|c|c|c|c|c|c|c|}
\hline Species & $\begin{array}{l}\text { Gene } \\
\text { pool }^{\text {a }}\end{array}$ & $\begin{array}{l}\text { ICP } \\
\text { no. }\end{array}$ & $\begin{array}{l}\text { Leaflet } \\
\text { length } \\
(\mathrm{cm})\end{array}$ & $\begin{array}{l}\text { Leaflet } \\
\text { width } \\
(\mathrm{cm})\end{array}$ & $\begin{array}{l}\text { Days to } \\
50 \% \\
\text { flowering }\end{array}$ & $\begin{array}{l}\text { Days to } \\
\text { maturity } \\
\text { (first } 5 \% \\
\text { pods) }\end{array}$ & $\begin{array}{l}\text { Pod } \\
\text { length } \\
(\mathrm{cm})\end{array}$ & $\begin{array}{l}\text { Pod } \\
\text { width } \\
(\mathrm{mm})\end{array}$ & $\begin{array}{l}\text { Seeds } \\
\text { per } \\
\text { pod }\end{array}$ & $\begin{array}{l}100 \\
\text { seed } \\
\text { weight } \\
(\mathrm{g})\end{array}$ & $\begin{array}{l}\text { Seed } \\
\text { protein } \\
\text { content } \\
(\%)\end{array}$ \\
\hline C. acutifolius & GP2 & 15611 & 4.1 & 1.7 & 140 & 220 & 2.5 & 9.0 & 4.0 & 2.4 & 20.6 \\
\hline C. albicans & GP2 & 15620 & 6.6 & 5.8 & 500 & 560 & 4.4 & 15.0 & 6.2 & 2.5 & 32.5 \\
\hline C. cajanifolius & GP2 & 15632 & 6.2 & 2.3 & 84 & 148 & 3.8 & 9.8 & 4.4 & 3.5 & 33.6 \\
\hline C. crassus & GP3 & 15768 & 8.3 & 6.5 & 168 & 240 & 3.5 & 10.0 & 4.7 & 3.8 & 33.8 \\
\hline C. lineatus & GP2 & 15646 & 4.3 & 1.5 & 160 & 220 & 2.1 & 9.4 & 2.4 & 2.0 & 30.2 \\
\hline C. mollis & GP3 & 15653 & 6.0 & 4.1 & 238 & 310 & 4.6 & 8.0 & 7.9 & 2.0 & 33.4 \\
\hline C. mollis & GP3 & 15658 & 6.8 & 4.3 & 222 & 340 & 5.0 & 7.4 & 8.6 & 2.0 & 21.7 \\
\hline C. platycarpus & GP3 & 15661 & 6.0 & 5.5 & 35 & 70 & 4.7 & 1.5 & 5.0 & 6.9 & 30.1 \\
\hline C. platycarpus & GP3 & 15664 & 6.6 & 5.9 & 34 & 64 & 4.7 & 1.5 & 5.1 & 6.3 & 17.9 \\
\hline C. platycarpus & GP3 & 15666 & 6.7 & 6.4 & 39 & 82 & 3.7 & 1.3 & 5.0 & 4.1 & 33.3 \\
\hline C. platycarpus & GP3 & 15668 & 7.1 & 6.5 & 35 & 73 & 4.3 & 1.4 & 5.4 & 5.9 & 31.3 \\
\hline C. platycarpus & GP3 & 15671 & 6.6 & 6.6 & 37 & 84 & 3.7 & 1.3 & 6.0 & 4.1 & 31.3 \\
\hline C. scarabaeoides & GP2 & 15922 & 3.5 & 1.8 & 62 & 102 & 2.7 & 8.0 & 4.8 & 2.9 & 22.3 \\
\hline C. sericeus & GP2 & 15760 & 2.6 & 5.2 & 100 & 134 & 1.2 & 6.4 & 2.0 & 1.7 & 30.6 \\
\hline
\end{tabular}

${ }^{a} G P 2$ secondary genepool and GP3 tertiary genepool

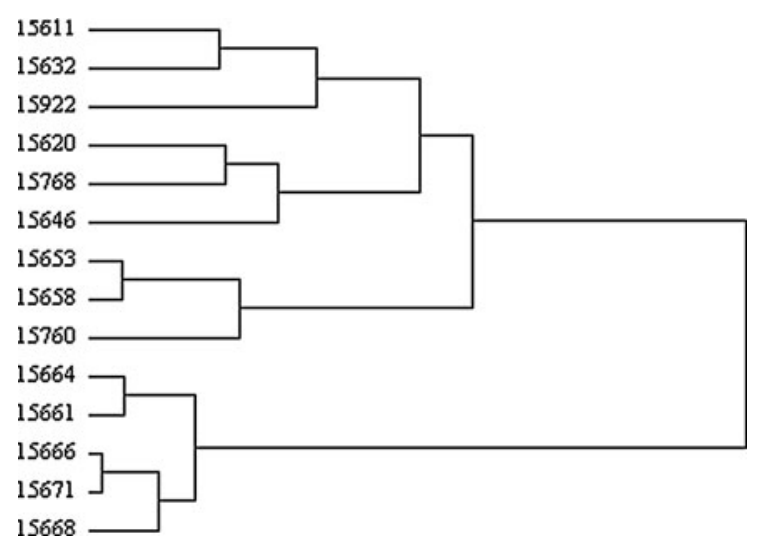

Fig. 2 Dendrogram of promising accessions belonging to different species based on Gower's dissimilarity matrix

geographical and taxonomical gaps in the collection. Hence, there is a need for critical assessment of existing Cajanus collection to identify geographical, taxonomical and diversity gaps and possibilities for exploration to fill these gaps before valuable material is lost forever due to rapid urbanization, shifting cultivation, forest fires, climate change, natural calamities, overgrazing, etc. (Upadhyaya and Gowda 2009). C. scarabaeoides, which has relatively more accessions (100) in the collection, was highly diverse for many traits emphasizing further exploration for all other species under study in priority areas for additional diversity.

Characterization refers to recording of distinctly identifiable, heritable characteristics, while preliminary evaluation involves recording of a limited number of important agronomic traits. At ICRISAT genebank, germplasm accessions were characterized and evaluated simultaneously. The main reason for characterization is to use wild species germplasm as a source for higher levels of resistance to biotic and abiotic stresses and for additional variability in agronomic traits. Characterization of wild species reveals the true potential of species in crop improvement and adaptation to the changing climate. But, characterization of wild relatives' germplasm is more problematic than characterization of cultivated germplasm. There may be several species of a crop with greater population differences on geographic scale, high genetic variability especially for flowering and maturity (both inter- and intra-species), range of breeding systems and perenniality of species (Lenne and David 1991). Lack of information on adaptation behavior of different species, variation in dormancy, germination, seed production, shattering are the other problems in characterization and evaluation of wild species. Probably because of the above mentioned reasons, only a 
Table 8 Most and least diverse accessions (ICP nos.) of different Cajanus species

\begin{tabular}{llllc}
\hline Species & Most diverse accessions & Distance & Least diverse accessions & Distance \\
\hline C. acutifolius & 15612 and 15610 & 0.555 & 15609 and 15607 & 0.017 \\
C. albicans & 15620 and 15901 & 0.507 & 15927 and 15925 & 0.013 \\
C. cajanifolius & 15630 and 15629 & 0.458 & 15873 and 15632 & 0.159 \\
C. crassus & 15776 and 15772 & 0.400 & 15770 and 15767 & 0.053 \\
C. lineatus & 15648 and 15645 & 0.461 & 15650 and 15649 & 0.091 \\
C. mollis & 15655 and 15653 & 0.671 & 15657 and 15654 & 0.055 \\
C. platycarpus & 15667 and 15664 & 0.501 & 15673 and 15665 & 0.010 \\
C. scarabaeoides & 15922 and 15913 & 0.361 & 15708 and 15697 & 0.000 \\
C. sericeus & 15762 and 15761 & 0.542 & 15763 and 15760 & 0.154 \\
\hline
\end{tabular}

small proportion of total wild relatives germplasm conserved in many genebanks including that of Cajanus collection at ICRISAT genebank has been characterized for morpho-agronomic traits (Jarvis et al. 2008).

Characterization and evaluation of different species by various researchers indicated that the wild pigeonpea genepool, particularly the genus Cajanus is a promising source for various biotic and abiotic stresses in addition to possessing some important agronomic traits (Mallikarjuna et al. 2011a; Reddy et al. 2000; Sharma et al. 1993; Sharma 2006; Srivastava et al. 2006). Most of the Cajanus species are palatable to cattle and goats, and many wild species of pigeonpea are useful in rearing lac insects (van der Maesen 1990). Therefore, the need to use wild Cajanus species, particularly from secondary genepool is well recognized. The results of the present study revealed that $C$. albicans, $C$. crassus, and $C$. mollis produced large leaves and high biomass for a longer period are important as animal feed. C. platycarpus and $C$. scarabaeoides were extra early and early flowering (ICRISAT 1978; Mallikarjuna et al. 2006; Upadhyaya 2006); C. albicans, C. crassus and C. marmoratus had broad pods; C. albicans, C. cajanifolius, C. cinereus, C. crassus, C. goensis, C. mollis, C. platycarpus and $C$. scarabaeoides had high seed number per pod (van der Maesen 1986), hence these are the species important for agronomic traits. Upadhyaya (2006) reported high pod set (74\% compared to about $20 \%$ in pigeonpea) in C. scarabaeoides. Therefore, all Cajanus species may be evaluated for this important trait. The highest seed protein content in the entire collection of cultivated pigeonpea was $30.8 \%$ (in ICP 15135). Evaluation of wild relatives' germplasm for seed protein content in the present study revealed that some accessions of $C$. crassus (33.8\%), C. cajanifolius $(33.6 \%)$, C. mollis $(33.4 \%)$, C. platycarpus $(33.3 \%)$ and $C$. albicans $(32.5 \%)$ as the best sources for higher levels of seed protein content (Reddy et al. 1997; Reddy et al. 2000; Saxena et al. 2002), but seeds are smaller.

The Cajanus species $C$. lineatus, $C$. platycarpus, $C$. scarabaeoides, C. sericeus, C. reticulatus, C. goensis, C. lanceolatus, C. latisepalus and C. marmoratus, which produced longer pod hairs with a score from 4 to 6 in the present study, may be useful in developing insect resistant pigeonpea cultivars. Rao et al. (2003) reported pod borer and podfly resistance in $C$. acutifolius, $C$. albicans, $C$. platycarpus, $C$. scarabaeoides, C. sericeus and C. reticulatus. Shanower et al. (1997) studied the survival, growth and fecundity of $H$. armigera on pods of $C$. cajan and two wild species and reported that larval survival on $C$. scarabaeoides was $21 \%$ compared to $57 \%$ on $C$. platycarpus and $78 \%$ on $C$. cajan. The dense covering of non-glandular trichomes on $C$. scarabaeoides acts as physical barrier and prevents small larvae reaching the surface of the pods.

Clustering of different species in this study was in agreement with studies of several researchers. Parani et al. (2000) reported a close genomic relationship between $C$. albicans and $C$. mollis, which formed Cluster 1 in the present study. Pundir and Singh (1985a) reported almost similar gross morphology and close association of $C$. lineatus and $C$. sericeus, which formed Cluster 3 in the present study. Nadimpalli et al. (1994) using RFLP also reported close relationship between these species. Pundir and Singh (1985a) reported close morphology between $C$. platycarpus 


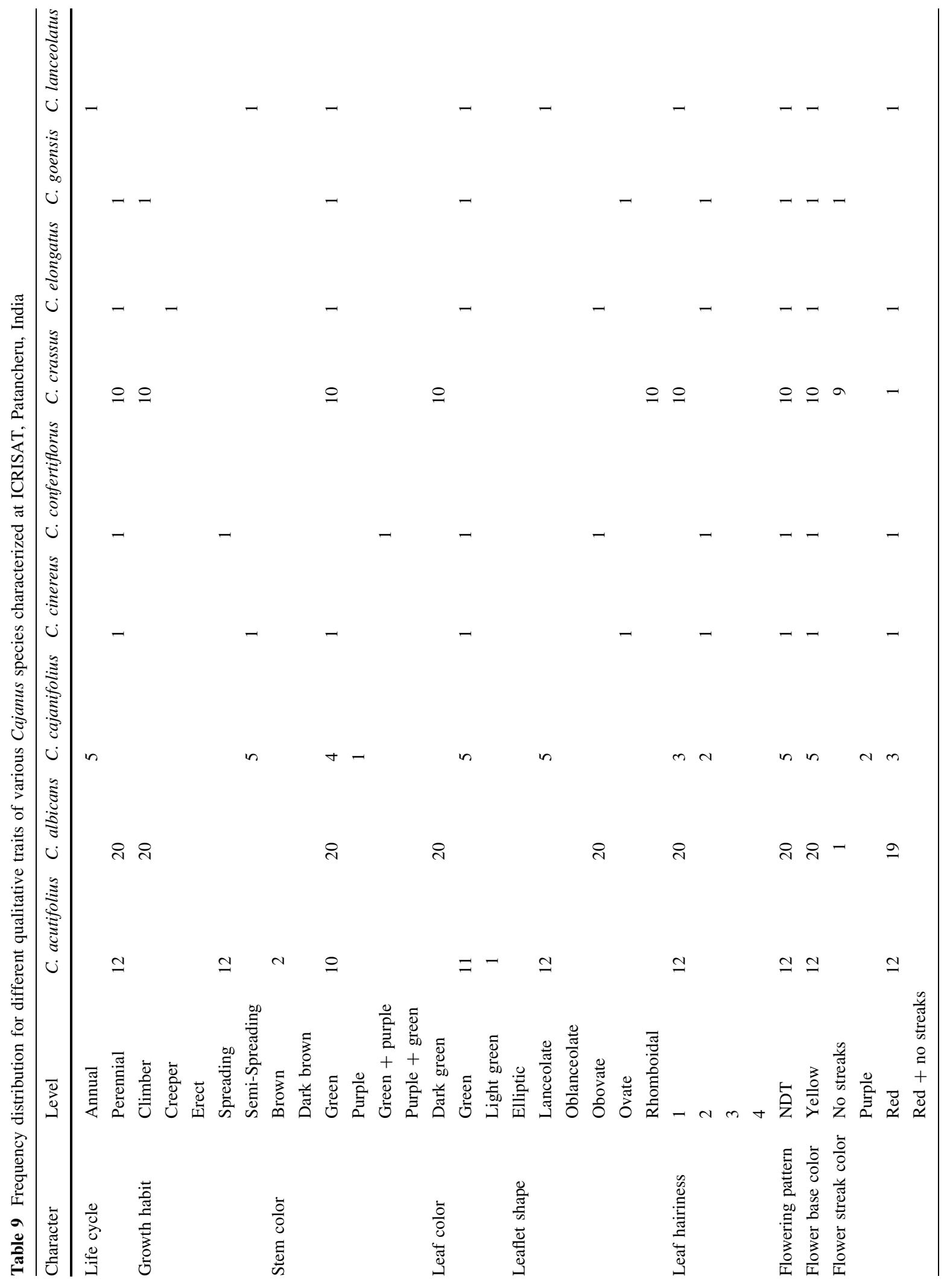




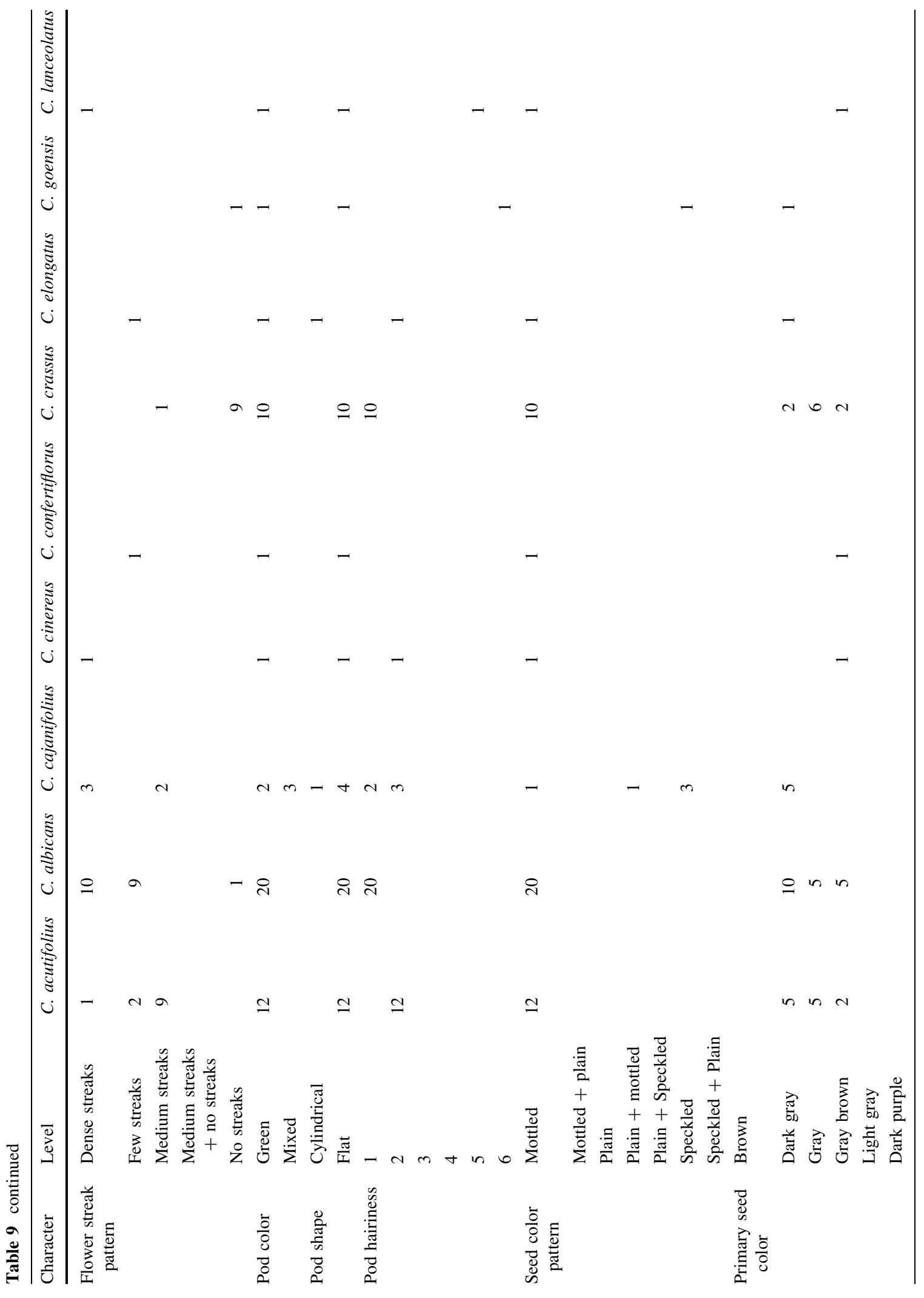




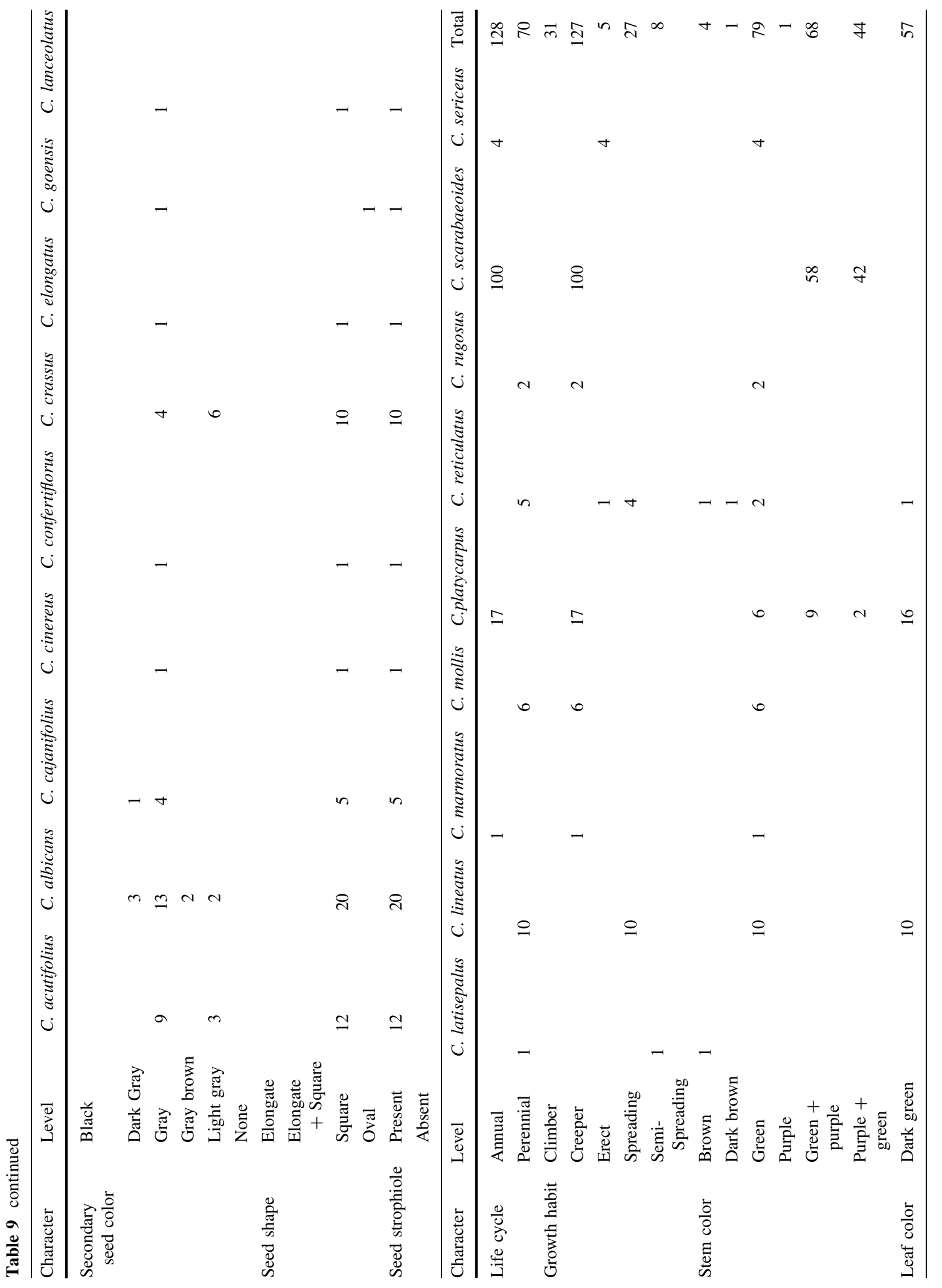




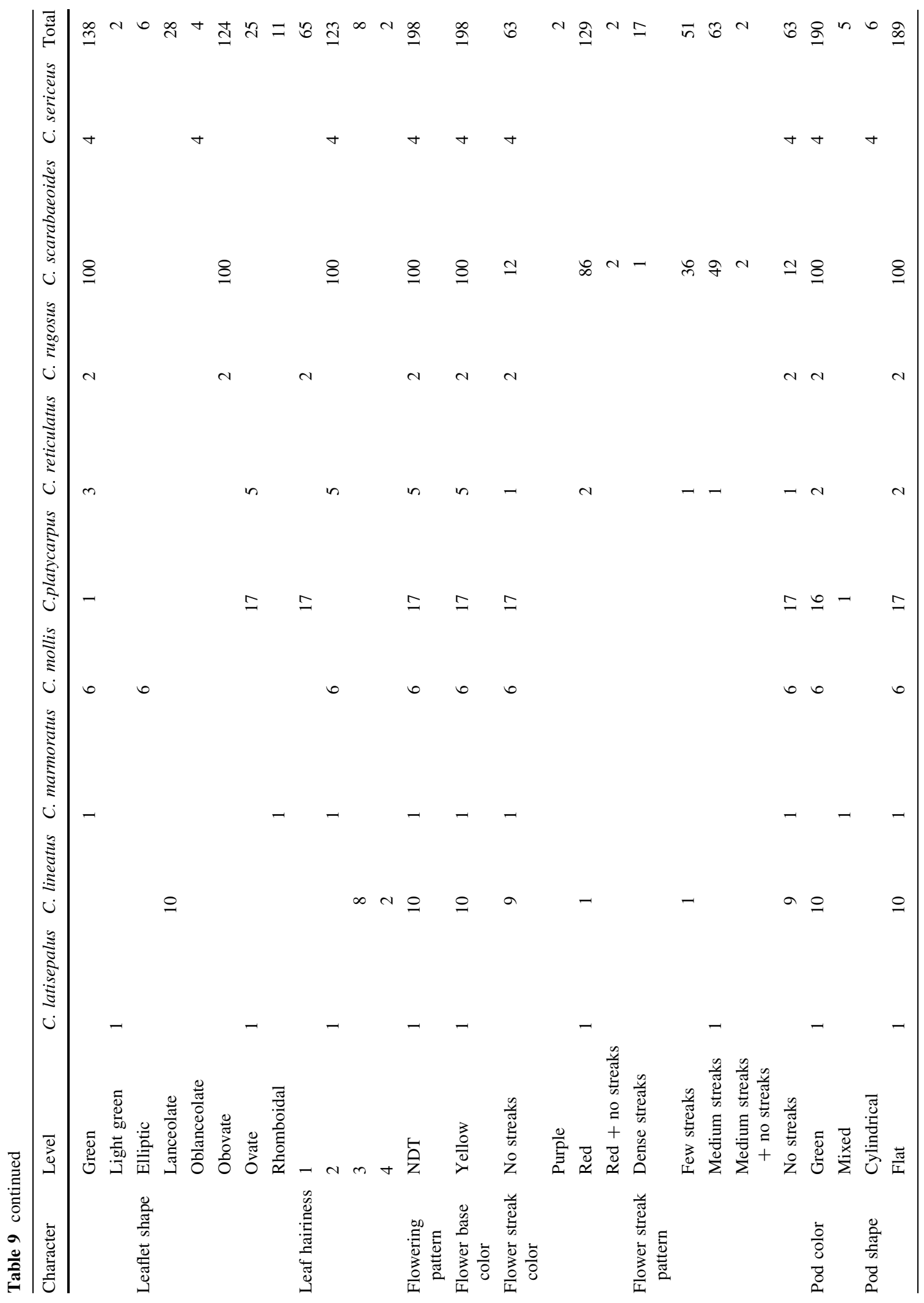


656

Genet Resour Crop Evol (2013) 60:639-659

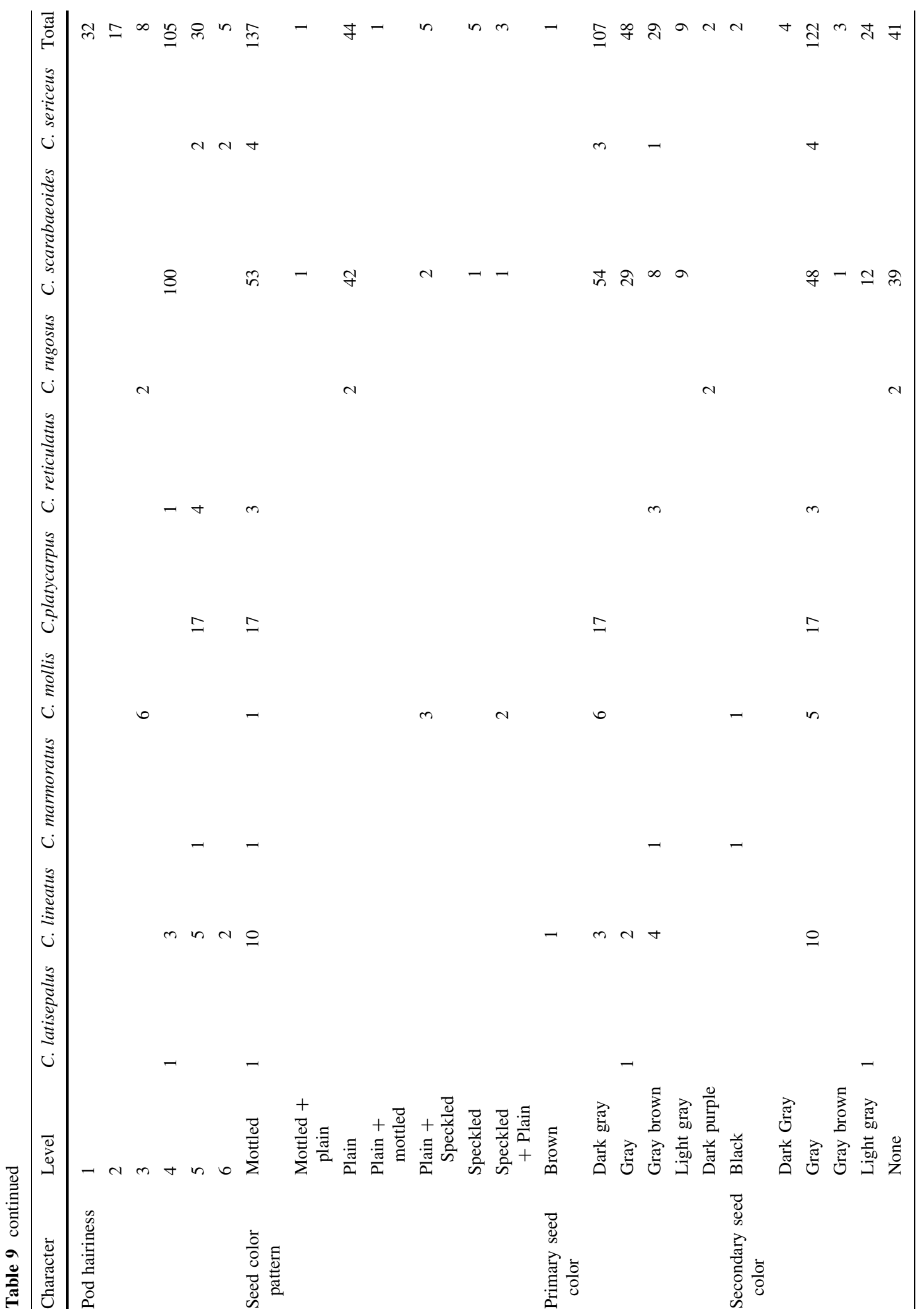

Springer 


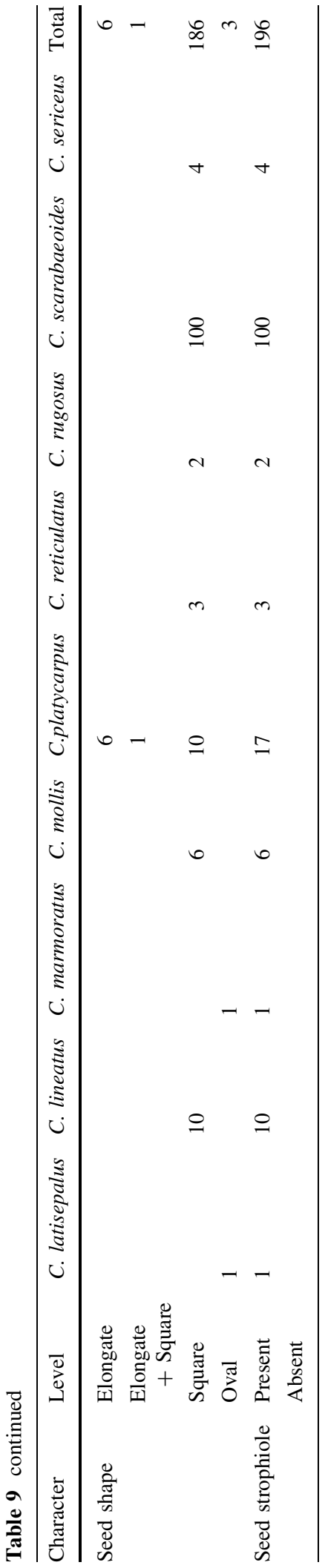

and $C$. crassus, and close karyotype symmetry between $C$. cajanifolius and C. crassus are in Cluster 2. Bio-systematic studies encompassing morpho-cytological and electrophoretic analysis of Cajanus species by Pundir and Singh (1985b) revealed that $C$. cajanifolius is closest to $C$. crassus and $C$. platycarpus. These three species are together in Cluster 2 in the present study. The clustering in the present study is based on phenotypic traits and may not have any phylogenetic significance. Pundir and Singh (1985a) reported the crossability between $C$. lineatus with $C$. scarabaeoides and $C$. scarabaeoides with $C$. sericeus, which are together in Cluster 3 in the present study. No association of genepool classification and clustering of species based on traits under study were observed and in every cluster there were species belonging to secondary and tertiary genepool (Figs. 1,2).

Information on character association is important in the classification of accessions and species. Highly significant positive correlation between leaflet length and width in $C$. albicans, and C. mollis, suggests the recording of leaflet length to assess the size of the leaf in these species (Table 6). These two species are of long duration (days to maturity $\geq 345$ days) can serve as good forage for cattle, goats and sheep. Significant positive correlation between days to $50 \%$ flowering and days to maturity (first 5 pods) over all species, $C$. acutifolius, C. crassus, C. lineatus, C. platycarpus and C. scarabaeoides suggests that selection for days to $50 \%$ flowering will result in selection for maturity also (Table 6) (van der Maesen 1990). Because of strong positive association between pod length with pod width in $C$. sericeus, with seeds per pod in $C$. lineatus and with 100-seed weight in C. platycarpus, selection for pod length will result in selection for broad pods, more seeds per pod and large seeds in these species. Flowering and maturity duration of species determines their adaptation to various agroclimatic conditions. These associations also have implications in reducing number of traits in characterization by using easily measurable correlated traits.

Availability of adequate genetic variation in germplasm collection is a prerequisite for a successful breeding program. In addition to using the cultivated pigeonpea germplasm collection, efforts can be made to explore and harness the genetic variation present in Cajanus species of secondary and tertiary genepools. These species may be exploited for useful agronomic traits such as extra early flowering in C. platycarpus, 
early flowering in $C$. scarabaeoides, long pods in $C$. mollis, broad pods in C. albicans, more seeds per pod in C. mollis, C. albicans, $C$. cinereus and C. scarabaeoides and high seed protein content in $C$. crassus, $C$. cajanifolius, C. mollis, C. platycarpus and C. albicans, using conventional breeding methods and/or biotechnology tools (Mallikarjuna and Moss 1995). Mallikarjuna et al. (2011b) used embryo rescue technique to transfer genes of resistance to phytophthora blight from C. platycarpus, which belongs to the tertiary genepool, to pigeonpea. The possibility of exploiting tertiary genepool has opened up new vistas for the broadening genetic base of variation and for pigeonpea improvement. Diverse and promising accessions of different species identified for multiple traits in the present study may be used for exploitation (Tables 7,8 ).

In view of changing climate scenario, results of the present study are useful to harness variation for useful traits in Cajanus genepool for sustainable pigeonpea improvement. The passport information on the Cajanus collection at ICRISAT genebank is available at http://www.icrisat.org/ICRISAT.crops.htm. The ICRISAT genebank serves as a major source for pigeonpea wild relatives' germplasm. Limited seeds of all in-trust accessions (with ITPGRFA/FAO) are available under Standard Material Transfer Agreement (SMTA) of the International Treaty for PGRFA, for utilization in research globally.

Acknowledgments Authors sincerely acknowledge the contribution of all former and present staff of Genetic Resources Unit (GRU), ICRISAT in collection, assembly and conservation of pigeonpea genetic resources. The help of Jacob Mathew, D. Bapa Rao, G. Dasaratha Rao and G. Ram Reddy, Research Technicians, Genetic Resources Unit, ICRISAT, Patancheru, India, in recording observations and documentation of the data for this study is highly appreciated.

\section{References}

Bohra A, Mallikarjuna N, Saxena KB, Upadhyaya HD, Vales I, Varshney R (2010) Harnessing the potential of crop wild relatives through genomics tools for pigeonpea improvement. J Plant Biol 37(1):85-100

Dodia DA, Patel AJ, Patel IS, Dhulia FK, Tikka SBS (1996) Antibiotic effect of pigeonpea wild relatives on Heliothis armigera. Int Chickpea Pigeonpea News1 3:100-101

Food and Agriculture Organization (2009) ORG/FAOSTAT database. http://www/FAO

Gower JC (1985) Measures of similarity, dissimilarity and distance. In: Kotz S, Johnson NL (eds) Encyclopedia of statistical sciences, vol 5. Wiley Interscience, New York, pp 397-405
IBPGR, ICRISAT (1993) Descriptors for pigeonpea [Cajanus cajan (L.) Millsp.]. IBPGR, Rome, Italy and ICRISAT, Patancheru, India, p 31

ICRISAT (International Crops Research Institute for the SemiArid Tropics) (1978) Annual report 1977/78. Patancheru, India, ICRISAT, p 295

Jarvis A, Lane A, Hijmans RJ (2008) The effect of climate change on crop wild relatives. Agric Ecosyst Environ. 126:13-23

Keuls M (1952) The use of the "studentized range" in connection with an analysis of variance. Euphytica 1:112-122

Lenne JM, David W (1991) Plant diseases and the use of wild germplasm. Annu Rev Phytopathol 29:35-63

Levene H (1960) Robust tests for equality of variances. In: Olkin I (ed) Contributions to probability and statistics: essays in honor of Harold Hotelling. Stanford University Press, Stanford, pp 278-292

Mallikarjuna N, Moss JP (1995) Production of hybrids between C. platycarpus and Cajanus cajan. Euphytica 83:43-46

Mallikarjuna N, Jadhav D, Reddy P (2006) Introgression of Cajanus platycarpus genome into cultivated pigeonpea, C. cajan. Euphytica 149:161-167

Mallikarjuna N, Saxena KB, Jadhav DR (2011a) Wild crop relatives. In: Kole $\mathrm{C}$ (ed) Genomic and breeding resources, legume crops and forages. Springer, Berlin-Heidelberg, pp 21-33

Mallikarjuna N, Senthilvel S, Deepak RJ, Saxena KB, Sharma HC, Upadhyaya HD, Rathore A, Varshney R (2011b) Progress in the utilization of Cajanus platicarpus (Benth.) Maesen in pigeonpea improvement. Plant Breed. doi: 10.1111/J.1439-0523.2011.01870.x

Nadimpalli RG, Jarret RL, Phatak SC, Kochart G (1994) Phylogenetic relationships of pigeonpea (Cajanus cajan) based on nuclear restriction fragment length polymorphism. Genome 36:216-223

Newman D (1939) The distribution of range in samples from a normal population expressed in terms of an independent estimate of standard deviation. Biometrika 31:20-30

Parani M, Lakshmi M, Senthil Kumar P, Parida A (2000) Ribosomal DNA variation and phylogenetic relationships among Cajanus cajan (L.) Millsp. and its wild relatives. Curr Sci 78(10):1235-1238

Pundir RPS, Singh RB (1985a) Crossability relationships among Cajanus, Atylosia and Rhynchosia species and detection of crossing barriers. Euphytica 34:303-308

Pundir RPS, Singh RB (1985b) Biosystematic relationships among Cajanus, Atylosia, and Rhynchocsia species and evolution of pigeonpea (Cajanus cajan (L.) Millsp.). Thoer Appl Genet 69:531-534

Rao NK, Reddy LJ, Bramel PJ (2003) Potential of wild species for genetic enhancement of some semi-arid food crops. Genet Resour Crop Evol 50:707-721

Reddy LJ, Saxena KB, Jain KC, Singh U, Green JM, Sharma D, Faris DG, Rao AN, Kumar RV, Nene YL (1997) Registration of high-protein pigeonpea elite germplasm ICPL 87162. Crop Sci 37:294

Reddy LJ, Bramel P, Saxena KB, Ortiz R (2000) Utilization of wild species in pigeonpea improvement at ICRISAT. In: Poster presented in international conference on science and technology for managing plant genetic diversity in the $21 \mathrm{st}$ century, Kuala Lumpur, Malaysia, 12-16 June 2000 
Remanandan P (1981) The wild genepool of Cajanus at ICRISAT, present and future. In. Proceedings of international workshop on pigeonpeas, vol 2, pp 29-38

Sahrawat KL, Ravi Kumar G, Murthy KVS (2002) Sulphuric acidselenium digestion for multi-element analysis in a single plant digests. Common soil Sci Plant Anal 33:3757-3765

Saxena KB, Kumar RV, Rao PV (2002) Pigeonpea nutrition and its improvement. In: Basara AS, Randhawa LS (eds) Quality improvement in field crops. Haworth Press, Binghamton, pp 227-260

Shannon CE, Weaver W (1949) The mathematical theory of communication. University of Illinois Press, Urbana

Shanower TG, Yoshida M, Peter AJ (1997) Survival, growth, fecundity and behavior of Helicoverpa armigera (Lepidoptera: Noctuidae) on pigeonpea and two wild Cajanus species. J Econ Entomol 90:837-841

Sharma HC (2006) Wild relatives of pigeonpea as sources of resistance to cotton bollworm/legume pod borer, Helicoverpa armigera (Hübner). Research briefs-biodiversity. http://www. icrisat.org/text/research/grep/homepage/grephomepage/ archives/wild.htm

Sharma SB, Remanandan P, McDonald D (1993) Resistance to Meloidogyne javanica and Rotylenchulus reniformis in wild relatives of pigeonpea. J Nematol 25:824-829

Sharma HC, Pampapathy G, Reddy LJ (2003) Wild relatives of pigeonpea as a source of resistance to the podfly (Melanagromyza obtusa Malloch) and pod wasp (Tanaostigmodes cajaninae La Salle). Genet Resour Crop Evol 50:817-824

Skinner SZ, Bauchan GR, Auricht G, Hughes S (1999) A method for the efficient management and utilization of large germplasm collections. Crop Sci 39:1237-1242
Snedecor GW, Cochran WG (1980) Statistical methods, 7th edn. Iowa State University Press, Ames

Srivastava N, Vadez V, Upadhyaya HD, Saxena KB (2006) Screening for intra and inter specific variability for salinity tolerance in pigeonpea (Cajanus cajan) and its related species. SAT eJournal 2(1). August 2006. ejournal.icrisat.org

Upadhyaya HD (2006) Improving pigeonpea with the wild. SAT Trends Newsl 62. Jan 2006. http://icrisat:8080/ satrends/jan2006.htm

Upadhyaya HD, Gowda CLL (2009) Managing and enhancing the use of germplasm-strategies and methodologies. Technical manual no. 10. International Crops Research Institute for the Semi-Arid Tropics, Patancheru

Upadhyaya HD, Reddy KN, Sharma S, Varshney RK, Bhattacharjee R, Singh S, Gowda CLL (2011) Pigeonpea composite collection and identification of germplasm for use in crop improvement programmes. Plant Genet Resour Charact Util 9(1):97-108

van der Maesen LJG (1986) Cajanus DC. and Atylosia W. \& A. (Leguminosae). Agricultural University Wageningen papers 85-4. Agricultural University, Wageningen, $225 \mathrm{pp}$

van der Maesen LJG (1990) Pigeonpea: origin, history, evolution and taxonomy. In: Nene YL, Hall SD, Sheila VK (eds) The pigeonpea. CAB International, Wallingford, pp 44-87

Wald A (1943) Test of statistical hypotheses concerning several parameters when the number of observations is large. Trans Am Math Soc 54:426-482. doi:10.1090/S0002-99471943-0012401-3

Ward JH (1963) Hierarchical grouping to optimize an objective function. J Am Stat Assoc 58:236 